\title{
Which Review Can Make You Engage? The Effect of Reviewer-Reader Similarity on Consumer-Brand Engagement
}

\author{
Senhui Fu, Guangdong University of Technology, Guangdong, China \\ Qing Yan, Jinan University, Guangdong, China \\ Guangchao Charles Feng, Shenzhen University, Shenzhen, China \\ Jiamin Peng, School of Management, Guangdong University of Technology, Guangzhou, China
}

\begin{abstract}
Online reviews facilitate customer-brand engagement, but few studies have explored this problem from the perspective of interpersonal attraction and its psychological mechanisms in the social commerce context. This paper aims to investigate the effect of reviewer-reader similarity (including external and internal similarity) in online reviews on customer-brand engagement in the social commerce context. Drawing upon the social categorization theory, a conceptual framework was developed and tested empirically. Data collected from a sample of Chinese consumers with the shopping experience on social commerce websites $(\mathrm{N}=392)$ was analyzed using partial least square (PLS). Findings reveal that both external and internal similarities are indirectly influenced consumer-brand engagement and mediated by consumers' perceived value and congruence transferred through this process. The impact of external similarity on customer-brand engagement was greater through consumers' perceived value, whereas the influence of internal similarity was stronger through consumers' self-brand congruence. Keywords Consumer-Brand Engagement, Perceived Value, Self-Brand Congruence, Social Commerce, Reviewer-Reader Similarity
\end{abstract}

\section{INTRODUCTION}

With the integration of Internet-based social life and business, social commerce is soaring (Wu, Quyen, \& Rivas, 2017). Publications recently have become more focus on studying social commerce (Kapoor, Tamilmani, Rana, Patil, Dwivedi, \& Nerur, 2018). For those firms who pursue their performance in social commerce, the issue of consumer engagement and how it further contributes in creating deeper and more lasting customer brand relationships has emerged (Kumar et al., 2010). As a typical type of e-WOM (Ismagilova, Dwivedi, Slade, \& Williams, 2017), online review is a main channel for consumers to present their attitudes or preferences towards a brand of all the commercial activities in social commerce context (Liang \& Turban, 2011), which also additionally enable customers to narrow the gap and diminish vulnerability for their choices (Mauri \& Minazzi, 2013).

DOI: 10.4018/JGIM.20211101.oa50

This article published as an Open Access article distributed under the terms of the Creative Commons Attribution License (http://creativecommons.org/licenses/by/4.0/) which permits unrestricted use, distribution, and production in any medium, provided the author of the original work and original publication source are properly credited. 
Online reviews on the social commerce website are useful, yet the genuineness and trustworthiness of the analysts often are doubted by the consumers (Shan, 2016). Research has demonstrated that users make their decisions depending on personal data about the commentators, for example, analyzing their profile to decide the helpfulness of their reviews (Forman et al., 2008; Liu \& Park, 2015), implying that customers don't allocate the same value to the data given by various people. Yaniv et al. (2011) suggested that customers like people who have similarity with themselves because similarity can build trust and reliability in the context of the face-to-face situation (He\& Bond, 2013; Yaniv et al., 2011). An industry overview demonstrates that $73 \%$ of customers concur that "people like me" are the most believable exhortation when making decisions (Marsden, 2009). Hence, we argue that the similarity effect also exists with regards to social business and take online reviews-related perception (perceived utilitarian and hedonic value) as motivational factors (Tamilmani, Rana, Prakasam, \& Dwivedi, 2019) to influence consumer engagement.

In brand relationship researches, other customers or the third person of the brand were positioned as non-product related attributes (Keller, 1993), impalpable resources (Kim \& Ko, 2012), or external communicators that are beyond the control of the organization (Bhattacharya \& Sen, 2003). As indicated by Martin (1996), consumers impact each other either straightforwardly through relational experiences or by implication by being part of the whole environment. Despite there is no interaction with other consumers in these indirect experiences, they might be increasingly pervasive and affect consumer to pick this brand (Ferraro et al., 2009). The consumer-based segment of social commerce involves how consumers' impression of other consumers' attributes and further impact their actions toward the brand (Brocato et al., 2012). In this respect, we take the brand-related psychological perception (self-image congruence and self-brand congruence) as another type of factors to affect customer brand engagement in the social commerce website.

Identifying the driving forces that influence customer brand engagement could encourage the scholars and marketers gain knowledge into how to deal with online reviewers towards a brand in the social commerce website. Although online reviews in e-commerce are referenced in several studies (Lui, Bartosiak, Piccoli, \& Sadhya, 2018; Mudambi, \& Schuff, 2010; Ismagilova et al., 2017; Siering, Muntermann, \& Rajagopalan,2018; Tamilmani, et al., 2019; Topaloglu, \& Dass, 2019), few studies have explored customer brand engagement from the perspective of reviewer-reader similarity (Akhtar, Kim, Ahmad, Akhtar, Siddiqi, \& Riaz, 2019; Chan, Lam, Chow, Fong, \&Law, 2017)) and its psychological mechanisms in social commerce context. Therefore, we argue that reviewer-reader similarity (external and internal similarity) in online reviews is crucial cues for customers who are willing to engage a brand in social commerce website.

The results of the quantitative analysis of PLS suggested that both external and internal similarity altogether influenced consumer brand engagement. External similarity exerted a more profound influence on consumers' perceived value, whereas internal similarity exerted a more profound influence on consumers' self-brand congruence, and finally both influenced consumers' brand engagement intention. Perceived utilitarian value and self-brand congruence mediated the relationship between reviewer-reader similarity and consumer brand engagement. This paper is an important contribution to academic marketing literature in the field of customer brand engagement and social psychological literature in the field of similarity effect, and provides useful managerial insights for marketing practitioners.

This rest paper is structured as follows: first, similarity-attraction theory is described as a hypothetical foundation related to customer perception (utilitarian and hedonic value), psychological cognition (self-image congruence and self-brand congruence) and behavioral activation (consumer brand engagement), then hypotheses and conceptual framework are proposed. Then, the research methodology, data analysis, and results are discussed. Finally, the conclusion and limitations are exhibited. 


\section{THEORETICAL BACKGROUND}

\subsection{Similarity-Attraction Theory and Similarity Category}

In sociology, we describe the similarity effect as the way in which people strongly prefer those who have similar characteristics to their own. The concept of similarity has been widely studied in the areas of psychology and marketing. Based on the hypothesis that similarity leads to attraction (Byrne, 1971). The similarity is characterized as "a match in demographic characteristics or in psychographic traits" (Shen et al., 2010). According to the homophily theory, similarity is "the degree to which pairs of individuals who interact are similar with respect to certain attributes, such as beliefs, values, education, social status, etc." (McPherson et al., 2001).As a type of interpersonal attraction, similarity has attraction that individuals make friends with and socialize with people to whom they consider similar, as similarity facilitates communication and breeds interpersonal connection (Byrne, 1971; Lau et al., 2008).

Drawing on the similarity-attraction theory (Byrne, 1971), this research presumes that during the procedure of product or brand selection, potential customers who read online reviews will in general think about the reviewer's personal characteristics (e.g., one's name or traits) (Yaniv et al., 2011), which is probably going to influence their evaluation about this product or brand on these social commerce websites. We explicitly look at the effect of the similarity between reviewer (i.e., the people who write online review) and reader (i.e., the potential customer who read the reviews) on customer brand engagement.

Theoretically, both external environmental factors and internal biological factors influence growth and development in humans. Similarities between humans can also be divided into external and internal similarities. Further, according to "visual cocktail party effect"(Moray, 1959; Henkaline, 2006) and "self-reference effect"(Markus, 1977; Symons,1997), we proposed that personal characteristics generate different effect and we divided it into two category: external similarity (e.g., one's name, place of residence, and etc.) and internal similarity(e.g., one's trait, value, and etc.).

\subsection{Self-Image and Self-Brand Congruence Theory}

Self-image congruence theory (Hosany \& Martin, 2012) suggests that consumers buy a particular product or brand that has functional congruence with their concept of "self" further embodying or improving their self-esteem or identity. Through consumers' needs of self-verification being satisfied, purchasers will, in general, assess a brand by coordinating their real feeling of self with the brand-buyer picture (Kressmann et al., 2006). Especially those who have a "non-complete self" tend to get or present the relative symbols (such as a brand) to perfect their identity image to fill this gap. Meanwhile, Andonova et al. (2015) showed self-brand congruence decidedly influences brand connection and consumer commitment, further influence brand loyalty. That is, the appeal of a brand is probably going to be identified with the degree to which consumers of the brand to be like them; such a brand conforms to their identity and offers the likelihood for self-articulation and positive assessment about this brand (Kressmann et al., 2006).

\section{HYPOTHESES DEVELOPMENT AND RESEARCH FRAMEWORK}

\subsection{The Effect of Similarity and Perceived Utilitarian Value}

Similarity between sales representatives and purchasers would make sales' proposals exceptionally convincing (Woodside \&Davenport, 1974) and increases their full of feeling bonds and encourages an impression of affinity (Smith et al., 2005). The impression of congruency may make up for the equivocalness of the data source's qualities, which are difficult to evaluate in a virtual domain (Smith et al., 2005). 
Utilitarian value mirrors a buyer's judgment on online reviews with respect to its practical, instrumental and social help for the individual's purchasing fulfillment. It is related to the intellectual parts of perceptions (eg., judgment of shopping proficiency, viability, and results) (Overby \& Lee, 2006). Therefore, for a consumer, a social commerce website that attracts similar consumers would more likely improve the person's achievements and let them perceive more utilitarian value.

In the field of face-to-face interpersonal communication, people are attracted by those who have external similarities(eg., one's name, place of residence, and etc.) with themselves at the very beginning when they have little interaction, whereas individuals are easier to be pulled in by those who have internal similarities (e.g., one's trait, value, and etc.) when they have deeper interaction. With regards to online reviews in social commerce websites, consumers (the reader of online reviewers) also have little interaction with the other consumers (the reviewer of online reviewers). Therefore, external reader-reviewer similarity is more related with constructive connections when they encountered first time (Gueguen \& Martin, 2009), which make a feeling of relationship between individuals, which prompts the upgrade of positive perceptions (e.g., Brack \& Benkenstein, 2012; Burger et al., 2004; Gueguen \& Martin, 2009; Jiang et al., 2010; Jones et al., 2004). In this way, we suggest that:

H1a: External similarity of online reviews between consumers has a positive influence on consumers' perceived utilitarian value of online reviews in social commerce websites.

H1b: Internal similarity of online reviews between consumers has a positive influence on consumers' perceived utilitarian value of online reviews in social commerce websites.

H1c: Compared to internal similarity, an external similarity of online reviews between consumers will have a stronger influence on consumers' perceived utilitarian value of online reviews in social commerce websites.

\subsection{The Effect of Similarity and Hedonic Value}

The similarity-attraction theory states that similar people have a higher shared fascination and more fulfilling connections (Byrne et al., 1967; Grange \& Benbasat, 2008). As mentioned before, purchasers' closeness in taste and inclination reinforces full of feeling bonds and affinity (Smith et al., 2005). Social network researchers showed that those who have similarities between each other are easier to form and maintain a relationship, including interpersonal ties, information exchange ties and reciprocity ties (McPherson et al., 2001; Shen et al., 2010). Since interfacing with comparable partners requires less cognitive exertion however yields more enjoyment (Al-Natour et al., 2011).

In reality, those married couples are progressively fulfilled in their connections when they have more similarities with their companions (Murray et al., 2002), which gives circuitous proof to the positive impact of the similarity impact on their happiness. When customers shop with others in the physical stores, they impart about similar preference and are better ready to evaluate merchandise. Customers are easier to acknowledge suggestions from the individuals who are like themselves in light of the fact that comparative data is seen as more relative (Bearden \& Etzel, 1982). It is reasonable to believe that when individuals communicate with the individuals who are like themselves, they take part in increasingly enthusiastic associations and feel more comfortable and increasingly enjoy talking with one another in the social commerce website. Therefore, we argue that this positive perception will delight users and further propose that a social commerce's capability for enabling purchasers to find similar ones will be helpful to their hedonic perception:

H2a: External similarity of online reviews between consumers has a positive influence on consumers' perceived hedonic value of online reviews in social commerce website.

$\mathrm{H} 2 \mathrm{~b}$ : Internal similarity of online reviews between consumers has a positive influence on consumers' perceived hedonic value of online reviews in social commerce website. 
H2c: Compared to internal similarity, an external similarity of online reviews between consumers will have a stronger influence on consumers' perceived hedonic value of online reviews in social commerce website.

\subsection{The Effect of Similarity on Self-Image Congruence}

Self-image was characterized as the totality of the person's contemplation and emotion regarding himself as an item (Rosenberg, 1979). A customer's mental self-image reflects what the individual considers himself and how he considers himself to be a social performing artist. Therefore, self-image congruence is characterized as the match between purchasers' self-concept (real self or ideal self) and his image (or "personality") of a given item, such as a product or brand (Kressmann et al., 2006). Both the similarity-attraction (Bryne, 1971) and social identity hypotheses (Tajfel and Turner, 1979) place that people lean toward associations with comparative others to keep up a predictable feeling of self (Marin \& Ruiz,2007). Individuals will in general showcase items and brands that mirror their mental self-image (Line et al., 2016). Therefore, similarities between consumers are an imperative influencing factor can affect the cognition of self-image congruence.

In the consumption set, when buyers find high similarity with other buyers of an organization, they will, in general, be more attached to that organization(Karaosmanoglu et al.,2011). Customers' self-confirmation needs lead to shape associations with brands related with reference groups matching with their self (Escalas \& Bettman, 2003). A consumer would like to choose products or brands that connect with other people who are like them in some remarkable characteristics(e.g. values, perspectives, feelings, and knowledge) (Reagans \& Burt, 1998; Karaosmanoglu et al.,2011).Because those goods and brands can fortify their mental self(Gardner\& Levy, 1955; Sirgy, 1982; Sirgy et al., 1997), which are consistent with their mental self and make an impression on others about their identity, what characteristics they have, what they esteem, and how they wish to be seen. The similarity facilitates behavioral mimicry (Guéguen \& Martin, 2009) to perceive self-image congruence with this social commerce website.

In addition, Lichtenthal and Tellefsen (2001) found that reviews that were centered on attributes had more grounded connections among comparability and deals execution than that concentrated on external perceptible qualities. In this way, we speculate that internal similarities between purchasers will more impact shoppers' apparent mental self-view coinciding in the social commerce website.

In sum, shoppers see high similarity to other clients of the brand impacts their relationship with a specific brand. Hence, we theorize that when the target customer sees a high level of comparability with alternate purchasers of a similar brand in the social commerce website, this similarity will prompt a generally elevated feeling of self-image consistency for that person:

H3a: External similarity of online reviews between consumers is positively associated with consumers' perceived self-image congruence towards a brand in social commerce websites.

$\mathrm{H} 3 \mathrm{~b}$ : Internal similarity of online reviews between consumers is positively associated with consumers' perceived self-image congruence towards a brand in social commerce websites.

$\mathrm{H} 3 \mathrm{c}$ : Compared to external similarity, an internal similarity of online reviews between consumers will have a stronger influence on consumers' perceived self-image congruence towards a brand in social commerce websites.

\subsection{The Relationship Between Self-Image Congruence and Hedonic Value}

The self is considered in an all-encompassing structure (Sirgy, 1982), which surpasses one's "possessions, perceptions and experiences" that establish oneself and reaches out to "persons, objects, places and group possessions" that form the extended self (Belk, 1988). Possession is not only a communicative and constructive device that maintains and enhances personal identity but it 
also mediates interpersonal relationships (Ahuvia, 2005; Belk, 1988). "Relationships with objects are never two-way (person-thing) but always three-way (person-thing-person)" (Belk, 1988).

Oneself is (Sirgy, 1982), which goes past one's "assets, observations and encounters" that "people, items, places and gathering assets" that frame the all-encompassing self (Belk, 1988). Ownership isn't just an open and helpful gadget that keeps up and upgrades individual character however it additionally intercedes relational connections (Ahuvia, 2005; Belk, 1988). "Associations with items are never two-way (individual thing) yet constantly three-way (individual thing-individual)" (Belk, 1988).

The symbolic interactionism theory proposes that items or brands are additionally utilized for impression supervision, which has emblematic implications and fills in as a type of emblematic correspondence between the customer and onlooker (Solomon, 1983). Particularly at the phase of procurement choice, purchasers might be progressively aware of the mental and social esteem and furthermore pay attention to the symbolic meaning of brands.

Online reviews and community of a brand in the social commerce website are the types of extended self through which customers find connections and develop a social identity dependent on the same involvement, eagerness, and encounters around a target brand (Muniz \& O'Guinn, 2001). Consumers maintaining a stronger relationship with the brand will bring more connection with other consumers (Algesheimer et al., 2005). When they endeavor to develop and characterize themselves, they endeavor to have brands the pictures of which are like their self-recognition and assemble connections that help their decisions and build a social identity. When consumers perceived more self-image congruence with other consumers in the reviews, they will enjoy their interaction and will be more pleasing and hedonic. Therefore, we postulate that the self-image congruence makes consumers fewer endeavors but yields more enjoyment (Al-Natour et al., 2011).

H4: Consumers' perceived self-image congruence has a positive influence on consumers' perceived hedonic value of online reviews in social commerce websites.

\subsection{The Relationship Between Hedonic Value and Utilitarian Value}

Prior studies have suggested that websites may be extensively described into two kinds: hedonic or utilitarian related (Heijden, 2004; Hartman et al., 2006; Massey et al., 2007). Consumers looking for hedonic and utilitarian gratification to assess certain properties of online stores (eg., visual structure, item variety, and data quality) (Koo et al., 2008). Online reviews, as a type of online information, can also satisfy shoppers' utilitarian or hedonic needs.

An online store with high utilitarian characteristics is intended to take care of an explicit issue (Park \& Moon, 2003), which aims to provide instrumental value (Massey et al., 2007), such as obtaining directions to buy products. Whereas, asocial commerce website with hedonic value is designed to provide hedonic pleasure, which aims to give enjoyment and delight to a consumer (Massey et al., 2007). The structure goal of a hedonic website centers around giving pleasurable encounters (Heijden, 2004). The website target of utilitarian is aimed to improve buyer re-patronage by offering rich encounters (Heijden, 2004), including consumers' pleasing experience. Hence, we suggest that:

H5: Consumers' perceived hedonic value of reviews has a positive influence on consumers' perceived utilitarian value of reviews in social commerce websites.

\subsection{The Effect of Utilitarian Value on Customer Brand Engagement}

In a broader development of the engagement concept, customer brand engagement (CBE) has evolved to be an important concept in marketing literature, which is believed to promote relational outcomes such as retention, positive word-of-mouth communication and loyalty through co-creation of customers' value (Verhoef, Reinartz, \& Krafft, 2010). In particular, consumers are viewed as proactive actors who devote relevant cognitive, emotional and physical resources to co-create value from specific brand interactions (Higgins \& Scholer, 2009). Evidence from extant literature on brand 
engagement shows that most research on CBE focuses on a specific brand - with the exception of Sprott, Czellar, and Spangenberg (2009) who focus on a set of brands that reflect consumers' selfconcept. Hollebeek et al. (2014) adopted a holistic perspective of a brand that includes consumers' perceived utilitarian, hedonic and symbolic aspects of the brand. In this study, we adopt the definition of CBE by Sprott, Czellar and Spangenberg (2009) as a 'consumers' propensity to include important brands as part of how they view themselves.

An e-commerce website empowers purchasers to find, share, suggest and rate items (Olbrich \& Holsing, 2011) in view of other consumers' online reviews. Because these mechanisms of social commerce reduce the intellectual cost of searching and help shoppers locate the suitable items more efficiently and effectively, even niche items (Phang et al., 2013). Other buyers, as the members of an internal group, enable the whole experience better for settling on buying choices. Consequently, customers will continue to use this website to exchange information and acquire commendation by exploiting this third-party resource.

Rivalry among marketers is currently to a great extent dependent on value-added methodologies expected to convey multi-value to purchasers. So it is crucial to identify which type of customer value is increasingly significant for marketers to compete with other merchants in the current market. Past research confirms that utilitarian value influences service satisfaction (Lichtlé et al., 2006) and customer loyalty (Chiu et al., 2006), further influences consumer brand engagement. This research, subsequently, exactly evaluates the impact of perceived utilitarian value on consumers brand engagement:

H6: Consumers' perceived utilitarian value of online reviews has a positive influence on their brand engagement in social commerce websites.

\subsection{The Effect of Congruence Transfer}

From a psychological comparison perspective, consumer behavior depends on the match between the product image and their self-concept (Cowart et al., 2008; Sirgy, 1985). Higher self-congruence is experienced when buyers feel that the item image coordinates their own mental self-image, while low self-congruence is experienced when the item image does not coordinate the customer's mental self-image (Cowart et al., 2008).

As recently examined, people are pulled in to brands that they feel express their identity or social status. In the field of brand, customers use brands to exchange with others about their identity, inclinations, and qualities. Meanwhile, consumers feel an association with brands that reflect their very own qualities. A person who feels a solid feeling of mental self-congruence with other purchasers verifies that the components of the brand are consistency with other similar customers. As needs are, such a purchase is probably going to fuse that brand into his view of himself (i.e., his mental self) so as to enable him to accomplish his personality objectives (Huffman et al., 2000).

The identity signaling theory supports this argument, which holds that people will, in general, select an item that accommodates their characters and will forsake that item if alternate buyers are from different out-groups (Berger, 2008). At the point when shoppers looked with copying practices by others whom they did not approve, they will show a negative attitude towards their most loved brands (Yang \& Mattila, 2014). As it were, different clients present can be seen as a visible cue of the brand and used to build their mental self-congruence. The mental self-image congruency will at that point fill in as a predecessor to trigger self-brand congruency.

When making a purchase decision, consumers resort to emblematic implications that upgrade their status and self-image (Palumbo \& Herbig, 2000). In this manner, purchasers select brands that project harmonious images with their own real, ideal, social, and ideal social images (Sirgy, 1985), called brand-image congruency. Brand exposure can impact shoppers to pick brands compatible with their very own images (Fitzsimons et al., 2008). Image congruency hypothesis proposes that image 
Figure 1. The research model

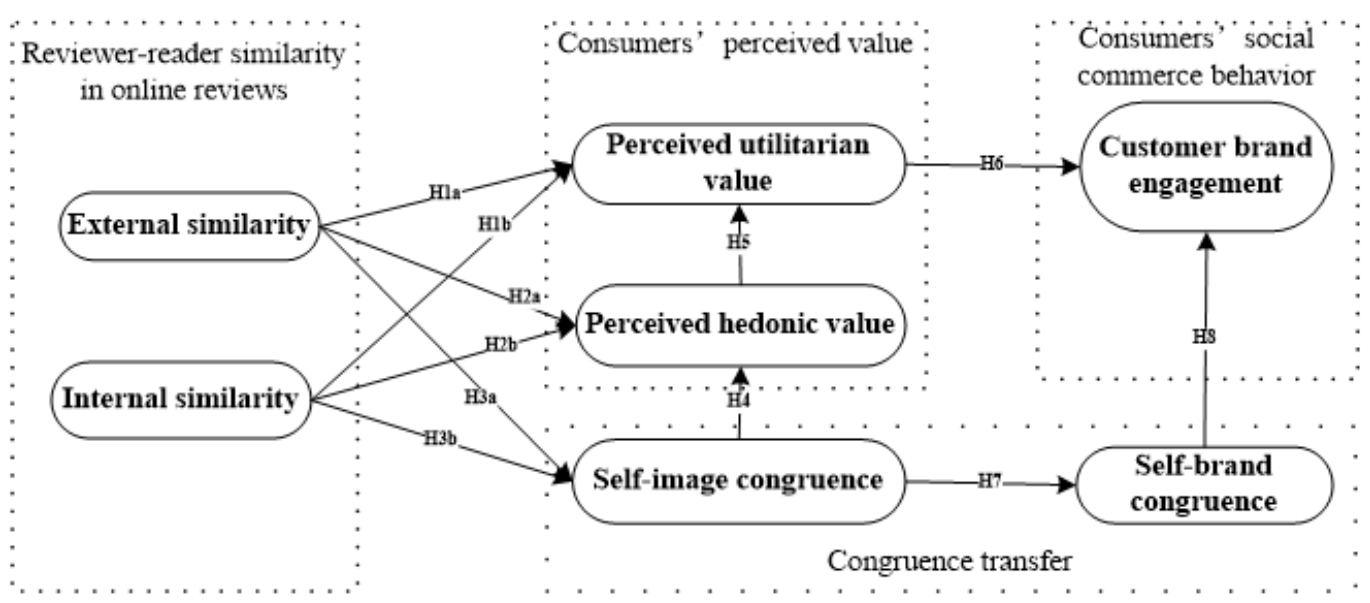

congruency has an imperative task in purchasing by building an association between the shopper and the brand.

Consumers have framed a "self-brand connection" in view of the consistency between the individual's "self-image" and "brand-image" (Escalas \& Bettman, 2005). Consumers utilize explicit brands as narrative content to convey who they are (Schembri et al., 2010). The self-brand congruency influences brand connection and consumer commitment (Andonova et al., 2015). When the e-commerce website shows this type of self-brand congruence elements sustainably and creatively, consumers prefer to stick to this website continually. Hence, it is expected that:

H7: Consumers' perceived self-image congruency has a positive influence on consumers' perceived self-brand congruence towards a brand in social commerce websites.

H8: Consumers' perceived self-brand consistency towards a brand has a positive influence on customer brand engagement in social commerce websites.

Further, the Stimulus-Organism-Response Model (Mehrabian \& Russell, 1974) provides us a structure that portrays similarity as a stimulus, both of perceived value and self-brand congruence constructs as a type of organism, while customer brand engagement as a sort of response(see Fig. 1).

\section{RESEARCH METHODOLOGY}

This paper plans to explore the similarity effect of online reviews on customer brand engagement in the context of social commerce from the perspective of consumers' perceived value and self-brand congruence. The exploration setting, online survey method, data gathering, examination, control variables, and common method bias will be portrayed as pursues.

\subsection{Research Setting}

This paper centers on similarities between consumers who are recognized from online reviews of social commerce websites, which allow consumers to interact with reviewers. We chose consumers who had shopping experience on social commerce websites, such as mogujie.com and meilishuo. com in Mainland China. It should be noted that these websites allow their consumers to create unique profiles, write and read online reviews from other consumers.Likewise, the links are useful in light 
of the fact that they exchange the purchaser's online associations to online buys; that is, customers' practices move from perusing to business. Hence, we trust that these sites give sufficient examples to researching online reviews based social business exercises in social commerce websites.

\subsection{Survey Design}

The reasons that we utilized an online review to test our examination demonstrate are as per the following. First, we managed an overview since this quantitative research strategy predicts conduct and analyzes the relations among variables and constructs (Newsted et al., 1998). Besides, the survey strategy has been generally utilized in exploring practices in social shopping context (Huang \& Benyoucef, 2014). In addition, utilizing an online survey keeps consistency between the exploration question and information gathering settings. Fourthly, an online survey has numerous different points of interest, for example, a wide reach and simple access to target buyers. In this way, we trust that the online survey is proper for the present investigation (Cheung \& Lee, 2009).

\subsection{Data Collection}

Since the investigation was led in Mainland China, so the scales in the poll experienced an interpretation and back interpretation process with the help of two doctoral understudies. Initial, one understudy interpreted the instruments from English to Chinese, and after that, the other understudy made an interpretation of them from Chinese to English. At that point, the two English variants of the scales were compared, and all irregularities were set out to enhance the validity. Further, we found specialists, including professors and doctoral understudies who studied marketing and psychology to assess the face validity of the study instruments for improvement. By and large, the survey was seen as brief and simple to finish. They proposed a few proposals for the arranging and wording of the questionnaire, which were fused in the final survey.

This investigation was presented as an "opinion survey" and the respondents were requested to review their ongoing social shopping encounters through perusing on the social commerce websites. At that point, they were requested to finish the survey dependent on their own encounters or observations. An opinion study is ordinarily used to see how respondents feel about target objects (e.g., Bagozzi \& Dholakia, 2006; Shen et al., 2014). Then, a screening question inquired as to whether potential respondents had involvement of perusing surveys and obtained items in social commerce websites (eg., meilishuo.com, and mogujie.com.) to guarantee that every respondent had related knowledge with social shopping. This technique is reliable with past examinations that embraced screening inquiries to recognize the most fitting respondents (e.g., Cheung \& Lee, 2009).

In this manner, we gathered an aggregate of 392 samples. We planned the last inquiry to decide if the respondents had cautiously perused and finished the poll, which brought about 22 respondents who picked "no." Thus, we at last acquired 370 usable samples. Note that a conceivable worry for our investigation is non-response bias, which happens when there is inclination from critical contrasts between non-respondents and respondents. Since it was unrealistic to think about these two gatherings of buyers in this examination, we pursued earlier research (e.g., Al-Qirim 2007) and compared the demographics for the early (the initial 50) and late (the last 50) respondents. This methodology sees late respondents as illustrative of non-respondents (Karahanna et al., 1999). The outcomes demonstrated that there were no significant differences. Henceforth, non-response predisposition is definitely not a basic issue in this investigation.

As appeared in Table 1, the example had $41.4 \%$ male and $58.6 \%$ female respondents. A large portion of the respondents $(85.7 \%$ ) were $18-35$, and $85.6 \%$ had a bachelor's degree or above. The statistic attributes of our example were reliable with the outcomes from an ongoing review, "Demographics of social media consumers" by the Pew Research Center (Duggan, 2015). 
Table 1. Demographics of respondents.

\begin{tabular}{|c|c|c|c|}
\hline \multicolumn{4}{|c|}{ Profile of respondents $(n=370)$} \\
\hline \multicolumn{4}{|l|}{ Frequency Percentage } \\
\hline Gender & $\begin{array}{l}\text { Male } \\
\text { Female }\end{array}$ & $\begin{array}{l}153 \\
217\end{array}$ & $\begin{array}{l}41.4 \\
58.6\end{array}$ \\
\hline Age & $\begin{array}{l}\leq 18 \\
18-25 \\
26-35 \\
36-45 \\
>45\end{array}$ & $\begin{array}{l}10 \\
186 \\
131 \\
37 \\
6\end{array}$ & $\begin{array}{l}2.7 \\
50.3 \\
35.4 \\
10 \\
1.6\end{array}$ \\
\hline Educational background & $\begin{array}{l}\text { High school or below } \\
\text { College } \\
\text { Bachelor's } \\
\text { Master's or above }\end{array}$ & $\begin{array}{l}5 \\
48 \\
241 \\
76\end{array}$ & $\begin{array}{l}1.4 \\
13.0 \\
65.1 \\
20.5\end{array}$ \\
\hline Income (RMB/Month) & $\begin{array}{l}\leq 2000 \\
2001-4000 \\
4001-8000 \\
8001-12000 \\
>12000\end{array}$ & $\begin{array}{l}143 \\
82 \\
79 \\
44 \\
22\end{array}$ & $\begin{array}{l}38.6 \\
22.2 \\
21.4 \\
11.9 \\
5.9\end{array}$ \\
\hline Occupation & $\begin{array}{l}\text { Student } \\
\text { Office staff } \\
\text { Self-employed } \\
\text { Others }\end{array}$ & $\begin{array}{l}143 \\
184 \\
21 \\
22\end{array}$ & $\begin{array}{l}38.6 \\
49.7 \\
5.7 \\
6.0\end{array}$ \\
\hline E-shopping experience & $\begin{array}{l}\leq 1 \text { year } \\
1-3 \text { years } \\
>3 \text { years }\end{array}$ & $\begin{array}{l}12 \\
51 \\
307\end{array}$ & $\begin{array}{l}3.2 \\
13.8 \\
83.0\end{array}$ \\
\hline Frequency of daily Internet use & $\begin{array}{l}2 \text { hours or less } \\
2-3 \text { hours } \\
\text { 3-4 hours } \\
4 \text { hours or more }\end{array}$ & $\begin{array}{l}11 \\
70 \\
98 \\
191\end{array}$ & $\begin{array}{l}3.0 \\
18.9 \\
26.5 \\
51.6\end{array}$ \\
\hline
\end{tabular}

\subsection{Measures}

All constructs were estimated measured by using multiple-item scales that were approved in earlier investigations. Minor adjustments were made to the measures to guarantee the face validity in this study (see Appendix A). Following Chavanat et al. (2009), a 6-point Likert scale, running from 1 (totally dissent) to 6 (totally concur), was utilized to keep Chinese respondents from picking an unbiased or irresolute point (e.g., 3 on a 5-point scale or 4 on a 7-point scale). Also, we utilized the interpretation-back-interpretation way to guarantee the consistency between the English and the Chinese instruments in light of the fact that the online survey was conducted in China.

\subsection{Control Variables}

Without haphazardly appointing participants, an online survey may increase the likelihood of systematic individual differences, which could impact the outcomes. Along these lines, this examination incorporated some control variables (eg.,gender, education background, occupation, and income) that measured customers' attributes on social commerce websites. Moreover, we likewise considered consumers' Internet encounter. 


\subsection{Common Method Bias}

All answers were gathered from one poll from one respondent; hence, common method bias could compromise the legitimacy of this investigation (Podsakoff et al., 2003). To begin with, Harman's single factor test (Podsakoff \& Organ, 1986) was led for the seven variables in our hypothetical model, including external similarity(ES), internal similarity (IS), perceived utilitarian value (PUV), perceived hedonic value (PHV), self-image congruence (SIC), self-brand congruence (SBC) and brand engagement intention(SI). The outcomes from this test demonstrated that no single factor clarified the majority of the variance, and the most variance that was clarified by one factor was $33.5 \%$, which recommends that common method bias was not a severe issue in the present examination.

Second, following Liang et al. (2007), we incorporated a common method factor in our conjectured model and enabled the constructs' indicators to reflectively associate with this factor. As appeared in Appendix B, the outcomes demonstrated that the substantive factor loadings were significant and high (average 0.839 and minimal 0.737 ), and the method factor loadings were low and non-significant (average 0.034 and maximum0.165). The average substantively clarified difference for the indicator was 0.707 , while the average common method variance was 0.003 . The proportion of substantive difference to method variance was roughly 118:1. Moreover, most of the method factor loadings were not significant, which recommends that common method bias is probably not going to be a severe issue.

\section{DATA ANALYSIS AND RESULTS}

This investigation utilized Smart PLS 3.0 to dissect the data. PLS is a component-based SEM approach that has been generally utilized in the current writing (e.g., Ahuja \& Thatcher, 2005; Xiang et al., 2016). Contrasted with covariance-based SEM (e.g., LISREL), PLS does not require a typical distribution (Chin, 1998), and it is the favored technique when the exploration objective is theory construction and forecast (Hair et al., 2011). Tamjidyamcholo et al. (2013) proposed that Smart PLS can formulate a formative model for latent constructs and has fewer limitations for the model check. Therefore, we selected the PLS instead of other SEM techniques. The research model was validated with two-step analytical procedures: the measurement and structural model (Hair et al., 1998).

\subsection{Measurement Model}

In the initial step, validity was evaluated with CFA. We utilized item loadings and the AVE to test the convergent validity. As appeared in Appendix A, all the items showed satisfactory convergent validity. The outcomes showed that all standardized item loadings were over the ideal value of 0.7 (Carmines \&Zeller, 1979) (see Appendix A).

Table 2 demonstrates that AVEs for all constructs extended from 0.610 to 0.867 , which were over the suggested estimation of 0.5 (Fornell\&Larcker, 1981). Composite reliability and Cronbach's alpha were utilized to test the construct reliability, as proposed by Fornell and Larcker (1981). The values for $\mathrm{CR}$ ran from 0.824 to 0.951 , which were higher than the benchmark estimation of 0.7 . The Cronbach's alpha extended from 0.710 to 0.923 , which were over the edge of 0.7 (Fornell \&Larcker, 1981). The outcomes suggested that our measurement model had adequate reliability.

Besides, the discriminant validity was evaluated by contrasting the square root of AVE with the correlations among the variables (Fornell \& Larcker, 1981). As appeared in Table 3, the square roots of the AVEs for all variables in the diagonal row were bigger than the correlations between variables. To additionally exam the validity of our estimation instruments, we built a cross-loadings table (see Appendix C), as recommended by Gefen et al. (2000). Every item loading in the table is higher than the other constructs, which bolsters satisfactory convergent and discriminant validity.

As appeared in Table 3, the internal-construct correlation values were above 0.6 , which shows that there might be multicollinearity. Along these lines, we examined for multicollinearity by investigating the Variance Inflation Factors (VIFs) and the tolerance values. Testing for multicollinearity requires 
Table 2. Results of the confirmatory factor analysis.

\begin{tabular}{|l|l|l|l|l|}
\hline \multicolumn{1}{|c|}{ Construct } & \multicolumn{1}{|c|}{ Items } & \multicolumn{1}{c|}{ Cronbach's Alpha } & \multicolumn{1}{c|}{$\begin{array}{c}\text { Composite } \\
\text { Reliability }\end{array}$} & \multicolumn{1}{c|}{ AVE } \\
\hline External similarity (ES) & 3 & 0.710 & 0.824 & 0.610 \\
\hline Internal similarity (IS) & 4 & 0.841 & 0.894 & 0.679 \\
\hline Perceived utilitarian value (PUV) & 4 & 0.814 & 0.878 & 0.644 \\
\hline Perceived hedonic value (PHV) & 4 & 0.797 & 0.867 & 0.620 \\
\hline Self-image congruence (SIC) & 3 & 0.880 & 0.926 & 0.807 \\
\hline Self-brand congruence (SBC) & 5 & 0.862 & 0.902 & 0.650 \\
\hline Customer brand engagement(CBE) & 3 & 0.923 & 0.951 & 0.867 \\
\hline
\end{tabular}

recognizing whether there are VIF values that are over 10 or have a tolerance value that is under 0.1 (Mason \& Perreault, 1991). The outcomes showed that the most noteworthy VIF was 2.825. In this way, multicollinearity is certifiably not a severe issue.

Note: Diagonal values in bold are the square root of the AVEs.

\subsection{Structural Model}

Fig. 2 (results from the PLS investigation) exhibits the outcomes from our exploration demonstrate with general explanatory power, estimated path coefficients (shown with asterisks) and the related t-values. Path significance tests were utilized a bootstrap re-sampling procedure.

As appeared in Fig.2, the outcomes show that the exogenous factors in the model somewhat clarify the variance in the endogenous factors. In particular, the coordinated model explained $22.8 \%$ of the variance in the online brand engagement in the social commerce websites. All hypotheses were fundamentally upheld.

As speculated, the outcomes exhibited: first, outside and internal similarity in context of a social commerce websites significantly impacted utilitarian value, with the coefficient of $0.218(0.164)$ (H1a and $\mathrm{H} 1 \mathrm{~b}$ were upheld). Second, external and inside similarity in online reviews of social commerce websites significantly impacted hedonic value, with the coefficient of $0.303(0.150)(\mathrm{H} 2 \mathrm{a}$ and $\mathrm{H} 2 \mathrm{~b}$ were upheld). Third, outside and interior similarity in online reviews of social commerce websites significantly impacted mental self-consistency, with the coefficient of $0.128(0.257)(\mathrm{H} 3 \mathrm{a}$ and $\mathrm{H} 3 \mathrm{~b}$ were upheld).

We further tested the statistically significant difference between the comparisons using the standardized coefficients. The outcomes bolstered our speculation that external similarity between

Table 3. Means, standard deviations and correlations.

\begin{tabular}{|l|l|l|l|l|l|l|l|l|l|}
\hline Variable & \multicolumn{1}{|c|}{ Mean } & \multicolumn{1}{|c|}{ S.D. } & \multicolumn{1}{|c|}{$\mathbf{1}$} & $\mathbf{2}$ & $\mathbf{3}$ & $\mathbf{4}$ & $\mathbf{5}$ & $\mathbf{6}$ & $\mathbf{7}$ \\
\hline 1. ES & 4.071 & 1.076 & $\mathbf{0 . 7 8 1}$ & & & & & & \\
\hline 2. IS & 4.121 & 1.152 & 0.516 & $\mathbf{0 . 8 2 4}$ & & & & & \\
\hline 3. PUV & 4.377 & 1.032 & 0.493 & 0.442 & $\mathbf{0 . 8 0 2}$ & & & & \\
\hline 4. PHV & 3.792 & 1.198 & 0.450 & 0.391 & 0.585 & $\mathbf{0 . 7 8 7}$ & & & \\
\hline 5. SIC & 3.196 & 1.287 & 0.260 & 0.322 & 0.391 & 0.212 & $\mathbf{0 . 8 9 8}$ & & \\
\hline 6. SBC & 3.319 & 1.271 & 0.222 & 0.288 & 0.345 & 0.255 & 0.686 & $\mathbf{0 . 8 0 6}$ & \\
\hline 7. CBE & 4.234 & 1.110 & 0.315 & 0.228 & 0.262 & 0.402 & 0.300 & 0.352 & $\mathbf{0 . 9 3 1}$ \\
\hline
\end{tabular}




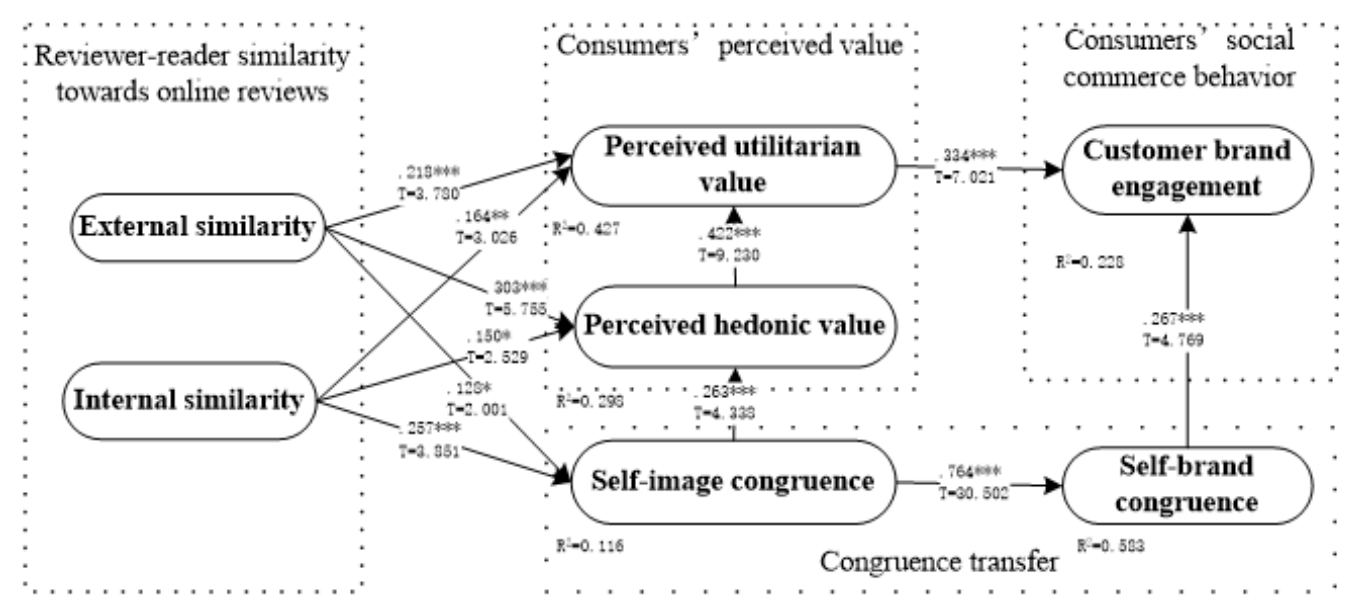

buyers will significantly impact purchasers' utilitarian value of online reviews in social commerce websites, with the standardized coefficients of $\beta_{\text {external }}=0.490$ and $\beta_{\text {internal }}=0.437$. And external similarity between buyers will significantly impact customers' hedonic value of online reviews in social commerce websites was additionally upheld, with coefficients of $\beta_{\text {external }}=0.434$ and $\beta_{\text {internal }}$ $=0.386$. At last, the speculations that internal similarity between customers will significantly affect purchasers' mental self-consistency was upheld, with coefficients of $\beta_{\text {internal }}=0.323$ and $\beta_{\text {external }}=0.263$ (H1c, H2c, and H3c were upheld).

Also, mental self-image consistency significantly impacted hedonic esteem, and further impacted utilitarian esteem, with coefficients of 0.263 and 0.422 , individually (H4 and $\mathrm{H} 5$ were upheld). Perceived utilitarian affected brand engagement with coefficients of 0.334 (H6 was upheld). Mental self-image harmoniousness impacted self-brand coinciding with coefficients of 0.764 (H7 was supported). Besides, self-brand compatibility affected brand engagement with coefficients of 0.267 (H8 was upheld).

All control factors were not significant, including gender $(\beta=0.03, \mathrm{p}>0.1)$, education background $(\beta=0.01, \mathrm{p}>0.1)$, occupation $(\beta=-0.01, \mathrm{p}>0.1)$, salary $(\beta=0.04, \mathrm{p}>0.1)$, and PC encounter $(\beta$ $=-0.05, \mathrm{p}>0.1)$.

As a post-doc investigation, in light of the technique for analyzing mediating effects, which was proposed by Zhao et al. (2010), we utilized a bootstrap strategy to test numerous mediator models (Preacher \&Hayes, 2008) to comprehend the mediating role of perceived utilitarian value (PUV), perceived hedonic value (PHV), self-image congruency (SIC) and self-brand congruency (SBC) in the examination model. To test the robustness of multiple mediation models, we utilized a $95 \%$ bootstrap confidence interval, in view of 5,000 bootstrapped samples (Hayes, 2013, model 4).

The aftereffects testing demonstrated that the aggregate indirect impact of external similarity on the brand engagement through PUV, PHV, SIC, and SBC was statistically significant (95\%CI: $\mathrm{LL}=0.132$, $\mathrm{UL}=0.335$ ), with an effect size of 0.225 . A closer examination demonstrated that there were indirect impacts of external similarity on brand engagement through PUV (95\%CI: LL $=0.125$, $\mathrm{UL}=0.290$ ), with an effect size of 0.198 ; the indirect impact of external similarity on self-brand congruency through SIC (95\%CI:LL=0.152, $\mathrm{UL}=0.339)$, with an effect size of 0.241 ; and the indirect effect of self-image congruence on brand engagement through SBC (95\%CI:LL=0.082, UL=0.305), with an effect size of 0.191 .

The aggregate indirect impact for internal similarity on the brand engagement through PUV, PHV, SIC, and SBC was likewise statistically significant (95\%CI: $\mathrm{LL}=.169, \mathrm{UL}=.336)$, with an effect 
size of 0.243 . In particular, there were indirect impacts for inward similarity on brand engagement through PUV(95\%CI: LL=0.121, UL=0.257), with an effect size of 0.179; the backhanded impact of internal similarity on self-brand consistency through SIC (95\%CI: LL $=0.178$, UL=0.348), with an effect size of 0.260. Likewise, the indirect impact of self-image consistency on utilitarian value through PHV (95\%CI: LL=0.118, UL=0.227), with an effect size of 0.167. These outcomes affirmed that PUV, PHV, SIC, and SBC assumed a full mediating role in the examination model.

\section{DISCUSSION AND CONCLUSION}

\subsection{Discussion of Key Findings}

This paper built and examined a conceptual model for the similarity effect on customer brand engagement social commerce websites. An alternate point of view was given from which to comprehend the nonstop support of social commerce websites by individual customers.

To begin with, there exists a similarity effect between reviewers and readers in online reviews of social commerce websites, which significantly affects customer brand engagement. As per the consequences of the PLS examination, the similarity effect can clarify $22.8 \%$ of the variance in purchasers' brand engagement. The finding confirmed the constructive outcome of similarity effect in the past research (Brack \& Benkenstein, 2012; Jiang et al., 2010; Martin et al., 2013).

Besides, there exist differences between external and internal similarity effect. External similarity has a greater effect on consumers' perceived utilitarian value and hedonic value than internal similarity does, whereas internal similarity has a greater effect on consumers' perceived self-image congruence.

Third, perceived utilitarian value (PUV), perceived hedonic value (PHV), self-image congruence (SIC) and self-brand congruence (SBC) in research model mediate the relationship between similarity and customer brand engagement in online reviews of social commerce websites. However, PUV and SBC are more profound to explain the variance than PHV and SIC, with $42.7 \%$ and $58.3 \%$ of the variance of the first two variables, while $29.8 \%$ and $11.6 \%$ of the variance of the last two.

\subsection{Theoretical Values}

This examination centers on customer brand engagement expectation, which was started by similarity between reviewer and reader in online reviews of social commerce websites. In particular, we analyzed how reviewers' external and internal similarity change readers' recognition and further influence the brand engagement expectation with regards to digital communication. By and large, this investigation enhances the current literature on the impacts of similarity in online reviews on customer social commerce behaviors in the following ways.

To begin with, we built a conceptual model integrating theories from sociology into IS the implementation that consolidated similarity between the reviewer and reader of online reviews. Prior studies on consumers' reviews often concentrated on the ratings and reviews themselves yet did not have the viewpoint of relational connections (e.g., similarity between reviewers and readers). In spite of the fact that Jiang et al. (2010) and Lichtenthal and Tellefsen (2001) analyzed the similarity effect, these examinations were not directed in the web-based shopping setting or concentrated on the consumer-salesman similarity(distinguished reviewer-reader similarity in this paper). This investigation found that similarity is a critical fringe cue for customers who are choosing to adhere to a social commerce website.

Second, we generate and examine research that external and internal similarity has an effect on decision-making processes but have greater impact through different paths, respectively, but they are integrated into one model. This is the primary endeavor to do as such in the writing on the similarity impact. This examination found that external similarity had a more significant influence on consumers' perceived value, further on customer brand engagement than internal similarity. Internal similarity, on the other hand, had a more profound effect on consumers' perceived self-image congruence and 
self-brand congruence, further on customer brand engagement than external similarity. This finding theoretically extends the connotation and context of the similarity effect as one of the most robust effects in the area of behavioral science (Berger, 1975).

Third, we give another hypothetical clarification to how similarity influences a customer brand engagement with psychological and motivational factors. We investigated the working mechanism of the similarity impact by looking at buyers' perceived value and self-brand congruence transfer. Not very many, assuming any, studies have analyzed the sorts of online reviews in social commerce websites that draw in purchasers to adhere to the sites and psychological mechanisms that underlie these practices, particularly from the point of view of social connections on shoppers' online practices (Mattila \& Wirtz, 2008).

\subsection{Practical Values}

What drives consumer brand engagement remains unresolved in social commerce research. From a practical standpoint, consumers' switching costs on the websites are low, so the discoveries of this examination will be helpful to social commerce websites to hold clients in the event that they exploit similarity in the context of online reviews (external similarity and internal similarity). The reason is that people are sensitive to online reviews wrote by similar others (Yaniv et al., 2011), particularly in the social commerce context (Kwok \& Yu, 2013). Our study develops a framework from the perspective of perceived value and self-brand congruence to address this research gap to further enable the marketer to take advantage of this positive effect with respect to online review management.

For social commerce websites design, researchers held that the web design can influence customers' choices to buy on the web (Hasan, 2016; Wu et al., 2017; Lightner et al., 2002). The components of a webpage that are enjoyable, engaging and interactive are bound to prompt inspirational dispositions toward the online brand (Huang et al., 2009), which may prompt an improved probability of buying (Chen et al., 2009). In addition, Al-Qeisi et al. (2014) demonstrated that a halo effect may impact the general assessment of a site on the grounds that the elements of value web composition are interrelated. This proposes enhancing the presence sequence of online reviews could lead to greater intention to engage. Specifically, when a brand or product are more related to external similarity (e.g., clothing and shoes), the website should primarily present the online reviews posted by those who have external similarity with the reader and vice versa. Moreover, websites can also remind consumers about other consumers similar to them and which brand they have purchased.

The firm should focus on the development of patterns in shoppers' similarity (e.g., phases of life, hobbies, and consumption preferences), to construct and adjust to purchasers' similarity presentation to upgrade their online review management. At the point when a shopper shares their statistic data or external similarity-related in their online profile, the practitioner should target this type of consumer to primarily present those online posted reviews by those who share external similarities with them and let them perceive utilitarian and hedonic value. Conversely, when a consumer shares more internal similarities in his or her online profile, the practitioner should target this type of consumer to primarily present those online reviews posted by those who share internal similarities with them and let them perceive self-image and self-brand congruence.

\subsection{Limitations and Future Research Headings}

The present investigation utilizes cross-sectional data. In the future, longitudinal research ought to be conducted and try to use data mining instead of self-reported survey.And experiments can give solid evidence of causality and enhance our comprehension of the causality (Dillon et al., 1984). In any case, given the restrictions in time and assets, cross-sectional investigations are utilized as exploratory vehicles that can decide the connections among variables.

Besides, we just analyzed similarity from the point of view of relational connections. There are different elements that influence customer's' practices (e.g., familiarity, expertise or liking). Additionally, there are other different components that influence customer brand engagement, for 
example, website quality, brand image or e-WOM. After all, this model gives explanatory power to customer brand engagement ( $23 \%$ of the variance clarified by perceived utilitarian value and selfbrand congruence only). In this way, we will additionally investigate the impacts of different factors on purchasers' online practices from alternate points of view.

What's more, the generalizability of the similarity impact that was delivered in our examination is restricted by the methodology and the explicit attributes of our investigation of social commerce websites. In particular, this examination utilizes the Chinese site (meilishuo.com and mogujie.com) in light of online surveys. In any case, we do trust that the similarity impact in our examination venture gives helpful rules to all online business websites. Extra research is expected to approve or enhance the research framework.

\section{FUNDING BODY}

This research was supported by Philosophy and Social Science Planning Project of Guangdong Province, China[GD20YGL02]; and Natural Science Foundation of Guangdong Province, China [2021A1515011438]. 


\section{REFERENCES}

Agarwal, R., \& Karahanna, E. (2000). Time flies when you're having fun: Cognitive absorption and beliefs about information technology usage. Management Information Systems Quarterly, 24(4), 665-694. doi:10.2307/3250951

Ahuja, M. K., \& Thatcher, J. B. (2005). Moving beyond intentions and toward the theory of trying: Effects of the work environment and gender on post-adoption information technology use. Management Information Systems Quarterly, 29(3), 427-459. doi:10.2307/25148691

Akhtar, N., Kim, W. G., Ahmad, W., Akhtar, M. N., Siddiqi, U. I., \& Riaz, M. (2019). Mechanisms of consumers' trust development in reviewers' supplementary reviews: A reviewer-reader similarity perspective. Tourism Management Perspectives, 31, 95-108. doi:10.1016/j.tmp.2019.04.001

Al-Natour, S., Benbasat, I., \& Cenfetelli, R. (2011). The adoption of online shoppingassistants: Perceived similarity as an antecedent to evaluative beliefs. Journal of the Association for Information Systems, 12(5), 347-374. doi:10.17705/1jais.00267

Al-Qeisi, K., Dennis, C., Alamanos, E., \& Jayawardhena, C. (2014). Website design quality and usage behavior: Unified Theory of Acceptance and Use of Technology. Journal of Business Research, 67(11), 2282-2290. doi:10.1016/j.jbusres.2014.06.016

Al-Qirim, N. (2007). A research trilogy into e-commerce adoption in small businesses in New Zealand. Electronic Markets, 17(4), 263-285. doi:10.1080/10196780701635872

Algesheimer, R., Dholakia, U. M., \& Herrmann, A. (2005). The social influence of brand community: Evidence from European car clubs. Journal of Marketing, 69(3), 19-34. doi:10.1509/jmkg.69.3.19.66363

Andonova, Y., Miller, E. G., \& Diamond, W. D. (2015). The Relationships among Self-Brand Congruence, Brand Attachment, Customer Engagement, and Brand Loyalty. Ideas in Marketing: Finding the New and Polishing the Old. Springer International Publishing.

Bagozzi, R. P., \& Dholakia, U. M. (2006). Open source software user communities: A study of participation in Linux user groups. Management Science, 52(7), 1099-1115. doi:10.1287/mnsc.1060.0545

Bearden, W. O., \& Etzel, M. J. (1982). Reference group influence on product and brand purchase decisions. The Journal of Consumer Research, 9(2), 183-194. doi:10.1086/208911

Berger, C. R. (1975). Task performance and attributional communication as determinants of interpersonal attraction. Speech Monographs, 40(4), 280-286. doi:10.1080/03637757309375805

Berger, J. (2008). Identity signaling, social influence, and social contagion. In M. Prinstein \& K. Dodge (Eds.), Peer Influence Processes Among Youth. GuilfordPress.

Bhattacharya, C. B., \& Sen, S. (2003). Consumer-company identification: A framework for understanding consumers' relationships with companies. Journal of Marketing, 67(2), 76-88. doi:10.1509/jmkg.67.2.76.18609

Bitner, M. J. (1992). Servicescapes: The impact of physical surroundings oncustomers and employees. Journal of Marketing, 56(2), 57-71. doi:10.1177/002224299205600205

Brack, A. D., \& Benkenstein, M. (2012). The effects of overall similarity regarding the customer-to-customerrelationship in a service context. Journal of Retailing and Consumer Services, 19(5), 501-509. doi:10.1016/j. jretconser.2012.06.006

Brocato, E. D., Voorhees, C. M., \& Baker, J. (2012). Understanding the influence of cuesfrom other customers in the service experience: A scale development and validation. Journal of Retailing, 88(3), 384-398. doi:10.1016/j. jretai.2012.01.006

Burger, J. M., Messina, N., Patel, S., del Prado, A., \& Anderson, C. (2004). What a coincidence! The effects of incidental similarity on compliance. Personality and Social Psychology Bulletin, 30(1), 35-43. doi:10.1177/0146167203258838 PMID:15030641

Byrne, D., Griffitt, W., \& Stefaniak, D. (1967). Attraction and similarity of personalitycharacteristics. Journal of Personality and Social Psychology, 5(1), 82-90. doi:10.1037/h0021198 PMID:4382219

Byrne, D. E. (1971). The attraction paradigm. Academic Press. 
Carmines, E. G., \& Zeller, R. A. (1979). Reliability and validity assessment. Academic Press.

Chanavat, N., Martinent, G., \& Ferrand, A. (2009). Sponsor and sponsees interactions: Effects on consumers' perceptions of brand image, brand attachment, and purchasing intention. Journal of Sport Management, 23(5), 644-670. doi:10.1123/jsm.23.5.644

Chen, J., Zhang, C., \& Xu, Y. (2009). The role of mutual trust in building members' loyalty to a C2C platform provider. International Journal of Electronic Commerce, 14(1), 147-171. doi:10.2753/JEC1086-4415140105

Cheung, C. M., \& Lee, M. K. (2009). Understanding the sustainability of a virtual community: Model development and empirical test. Journal of Information Science, 35(3), 279-298. doi:10.1177/0165551508099088

Chin, W. W. (1998). The partial least squares approach for structural equation modeling. In M. Ga (Ed.), Reference 99 modern methods for business research (pp. 295-336). Lawrence Erlbaum Associates.

Chiu, H. C., Hsieh, Y. C., Li, Y. C., \& Lee, M. (2006). Relationship marketing and consumer switching behavior. Journal of Business Research, 58(12), 1681-1689. doi:10.1016/j.jbusres.2004.11.005

Cowart, K. O., Fox, G. L., \& Wilson, A. E. (2008). A structural look at consumer innovativeness and selfcongruence in new product purchases. Psychology and Marketing, 25(12), 1111-1130. doi:10.1002/mar.20256

Dillon, W. R. G., Dillon, M. W. R., \& Goldstein, M. (1984). Multivariate analysis methods and applications (No. 519.535 D5). Academic Press.

Duggan, M. (2015). Social media update 2015. Pew Research Center.

Edward Shih-Tse, W. (2010). Internet Usage Purposes and Gender Differences in the Effects of Perceived Utilitarian and Hedonic Value. Cyberpsychology, Behavior, and Social Networking, 13(2), 179-183. doi:10.1089/ cyber.2009.0200 PMID:20528275

Escalas, J. E., \& Bettman, J. R. (2003). You are what they eat: The influence of reference groups on consumers' connections to brands. Journal of Consumer Psychology, 13(3), 339-348. doi:10.1207/S15327663JCP1303_14

Escalas, J. E., \& Bettman, J. R. (2005). Self-construal, reference groups, and brand meaning. The Journal of Consumer Research, 32(3), 378-389. doi:10.1086/497549

Ferraro, R., Bettman, J. R., \& Chartrand, T. L. (2009). The power of strangers: The effect of incidental consumer brand encounters on brand choice. The Journal of Consumer Research, 35(5), 729-741. doi:10.1086/592944

Fitzsimons, G. M., Chartrand, T. L., \& Fitzsimons, G. J. (2008). Automatic effects of brand exposure on motivated behavior: How apple makes you "think different". The Journal of Consumer Research, 35(1), 21-35. doi: $10.1086 / 527269$

Forman, C., Ghose, A., \& Wiesenfeld, B. (2008). Examining the relationship betweenreviews and sales: The role of reviewer identity disclosure in electronicmarkets. Information Systems Research, 19(3), 291-313. doi:10.1287/isre.1080.0193

Fornell, C., \& Larcker, D. F. (1981). Evaluating structural equation models with unobservable variables and measurement error. JMR, Journal of Marketing Research, 18(1), 39-50. doi:10.1177/002224378101800104

Gardner, B. B., \& Levy, S. J. (1955). The product and the brand. Harvard Business Review, 33(2), 33-39.

Gefen, D., Straub, D., \& Boudreau, M. C. (2000). Structural equation modeling and regression: Guidelines for research practice. Communications of the Association for Information Systems, 4(1), 7. doi:10.17705/1CAIS.00407

Grange, C., \& Benbasat, I. (2008). Strategies used for consumers to extract valuefrom online shopping networks. In Social mediating technologies workshop, 27th CHI conference. ACM.

Granovetter, M. (1985). Economic action and social structure: The problem of embeddedness. American Journal of Sociology, 91(3), 481-510. doi:10.1086/228311

Guéguen, N., \& Martin, A. (2009). Incidental similarity facilitates behavioral mimicry. Social Psychology, 40(2), 88-92. doi:10.1027/1864-9335.40.2.88

Hair, J. F., Anderson, R. E., Tatham, R. L., \& Black, W. (1998). Multivariate Data Analysis (5th ed.). Prentice Hall International. 
Hair, J. F., Ringle, C. M., \& Sarstedt, M. (2011). PLS-SEM: Indeed a silver bullet. Journal of Marketing Theory and Practice, 19(2), 139-152. doi:10.2753/MTP1069-6679190202

Hartman, J. B., Shim, S., Barber, B., \& O'Brien, M. (2006). Adolescents' utilitarian and hedonic web consumption behavior: Hierarchical influence of personal values and innovativeness. Psychology and Marketing, 23(10), 813-839. doi:10.1002/mar.20135

Hasan, B. (2016). Perceived irritation in online shopping: The impact of website design characteristics. Computers in Human Behavior, 54, 224-230. doi:10.1016/j.chb.2015.07.056

Hayes, A. F. (2013). Introduction to Mediation, Moderation, and Conditional Process Analysis: A RegressionBased Approach. Academic Press.

He, S. X., \& Bond, S. D. (2013). Word-of-mouth and the forecasting of consumptionenjoyment. Journal of Consumer Psychology, 23(4), 464-482. doi:10.1016/j.jcps.2013.04.001

Heijden, H. (2004). User acceptance of hedonic information systems. Management Information Systems Quarterly, 28(4), 695-704. doi:10.2307/25148660

Henkaline, \& Ty, C. (2006). A visual cocktail party effect: the role of meaningfulness in perception: an honors thesis (honrs 499). Psychology.

Hollebeek, L. D., Glynn, M. S., \& Brodie, R. J. (2014). Consumer brand engagement in social media: Conceptualization, scale development and validation. Journal of Interactive Marketing, 28(2), 149-165. doi:10.1016/j.intmar.2013.12.002

Hosany, S., \& Martin, D. (2012). Self-image congruence in consumer behavior. Journal of Business Research, 64(10), 685-691. doi:10.1016/j.jbusres.2011.03.015

Huang, P., Lurie, N. H., \& Mitra, S. (2009). Searching for experience on the web: An empirical examination of consumer behavior for search and experience goods. Journal of Marketing, 73(2), 55-69. doi:10.1509/ jmkg.73.2.55

Huang, Z., \& Benyoucef, M. (2014). User preferences of social features on social commerce websites: An empirical study. Technological Forecasting and Social Change, 95, 57-72. doi:10.1016/j.techfore.2014.03.005

Huffman, C., Ratneshwar, S., \& Mick, D. G. (2000). Consumer goal structures andgoal-determination processes. In The Why of Consumption: Contemporary Perspectives on Consumer Motives, Goals, and Desires (pp. 9-35). Routledge.

Irene, C. C. C., Lam, L. W., Chow, C. W. C., Lawrence, H. N. F., \& Law, R. (2017). The effect of online reviews on hotel booking intention: The role of reader-reviewer similarity. International Journal of Hospitality Management, 66, 54-65. doi:10.1016/j.ijhm.2017.06.007

Ismagilova, E., Dwivedi, Y. K., Slade, E., \& Williams, M. D. (2017). Electronic word of mouth (eWOM) in the marketing context: A state of the art analysis and future directions. Springer. doi:10.1007/978-3-319-52459-7

Ji, R., \& Meeker, M. (2005). Creating consumer value in digital China. Morgan Stanley.

Jiang, L., Hoegg, J., Dahl, D. W., \& Chattopadhyay, A. (2010). The persuasive role of incidental similarity on attitudes and purchase intentions in a sales context. The Journal of Consumer Research, 36(5), 778-791. doi: $10.1086 / 605364$

Jones, J. T., Pelham, B. W., Carvallo, M., \& Mirenberg, M. C. (2004). How do I love thee? let me count the js: Implicit egotism and interpersonal attraction. Journal of Personality and Social Psychology, 87(5), 665-683. doi:10.1037/0022-3514.87.5.665 PMID:15535778

Jones, M. A., Reynolds, K. E., \& Arnold, M. J. (2006). Hedonic and utilitarian shopping value: Investigating differential effects on retail outcomes. Journal of Business Research, 59(9), 974-981. doi:10.1016/j. jbusres.2006.03.006

Kapoor, K. K., Tamilmani, K., Rana, N. P., Patil, P., Dwivedi, Y. K., \& Nerur, S. (2018). Advances in social media research: Past, present and future. Information Systems Frontiers, 20(3), 531-558. doi:10.1007/s10796-017-9810-y 
Karahanna, E., Straub, D. W., \& Chervany, N. L. (1999). Information technology adoption across time: A crosssectional comparison of pre-adoption and post-adoption beliefs. Management Information Systems Quarterly, 23(2), 183-213. doi:10.2307/249751

Karaosmanoglu, E., Bas, A. B. E., \& Zhang, J. K. (2011). The role of other customer effect incorporates marketing: Its impact on corporate image and consumer-company identification. European Journal of Marketing, 45(9-10), 1416-1445. doi:10.1108/03090561111151835

Keller, K. L. (1993). Conceptualizing, measuring, andmanaging customer-based brand equity. Journal of Marketing, 57(1), 1-22. doi:10.1177/002224299305700101

Kim, A. J., \& Ko, E. (2012). Do social media marketing activities enhance customer equity?An empirical study of luxury fashion brand. Journal of Business Research, 65(10), 1480-1486. doi:10.1016/j.jbusres.2011.10.014

Koo, D., Kim, J., \& Lee, S. (2008). Personal values as underlying motives of shopping online. Asia Pacific Journal of Marketing and Logistics, 20(2), 156-173. doi:10.1108/13555850810864533

Kressmann, F., Sirgy, M. J., Herrmann, A., Huber, F., Huber, S., \& Lee, D. J. (2006). Directand indirect effects of self-image congruence on brand loyalty. Journal of Business Research, 59(9), 955-964. doi:10.1016/j. jbusres.2006.06.001

Kwok, L. C., \& Yu, B. (2013). Spreading social media messages on Facebook: An analysis of restaurant businessto-consumer communications. Cornell Hospitality Quarterly, 54(1), 84-94. doi:10.1177/1938965512458360

Li, D., Browne, G., \& Wetherbe, J. (2006). Why do internet users stick with a specific web site? a relationship perspective. International Journal of Electronic Commerce, 10(4), 105-141. doi:10.2753/JEC1086-4415100404

Liang, H., Saraf, N., Hu, Q., \& Xue, Y. (2007). Assimilation of enterprise systems: The effect of institutional pressures and the mediating role of top management. Management Information Systems Quarterly, 31(1), 59-87. doi: $10.2307 / 25148781$

Liang, T. P., \& Turban, E. (2011). Introduction to the special issue of social commerce: A research framework for social commerce. International Journal of Electronic Commerce, 16(2), 5-14. doi:10.2753/JEC1086-4415160201

Lichtenthal, J. D., \& Tellefsen, T. (2001). Toward a theory of business buyer-seller similarity. Journal of Personal Selling \& Sales Management, 21(1), 1-14.

Lichtlé, M. C., Cottet, P., \& Plichon, V. (2006). The role of value in services: a study in a retail environment. Post-Print, 23(4), 219-227.

Lightner, N. J., Yenisey, M. M., Ozok, A. A., \& Salvendy, G. (2002). Shopping behavior and preferences in e-commerce of Turkish and American university students: Implications from cross-cultural design. Behaviour \& Information Technology, 21(6), 373-385. doi:10.1080/0144929021000071316

Line, N., Hanks, L., \& Kim, W. G. (2016). (in the press). An expanded servicescape framework as thedriver of place attachment and word of mouth. Journal of Hospitality \& Tourism Research (Washington, D.C.).

Liu, Z., \& Park, S. (2015). What makes a useful online review? The implication for travelproduct websites. Tourism Management, 47, 140-151. doi:10.1016/j.tourman.2014.09.020

Lowry, P. B., Romano, N. C., Jenkins, J. L., \& Guthrie, R. W. (2009). The CMC interactivity model: Howinteractivity enhances communication quality and process satisfaction in lean-media groups. Journal of Management Information Systems, 26(1), 155-196. doi:10.2753/MIS0742-1222260107

Lui, T.-W., Bartosiak, M., Piccoli, G., \& Sadhya, V. (2018). Online review response strategy and its effects on competitive performance. Tourism Management, 67, 180-190. doi:10.1016/j.tourman.2018.01.014

Marin, L., \& Ruiz, S. (2007). "I need you too!" corporate identity attractiveness for consumersand the role of social responsibility. Journal of Business Ethics, 71(3), 245-260. doi:10.1007/s10551-006-9137-y

Marsden, P. (2009). Top social commerce survey findings. Available at https://socialcommercetoday.com/topsocialcommerce-survey-findings-ripple6/

Martin, A., Jacob, C., \& Gueguen, N. (2013). Similarity facilitates relationships on social networks: A field experiment on Facebook. Psychological Reports, 112(3), 1-4. doi:10.2466/21.07.PR0.113x15z8 PMID:24340812 
Martin, C. L. (1996). Consumer-to-consumer relationships: Satisfaction with other consumers'public behavior. The Journal of Consumer Affairs, 30(1), 146-169. doi:10.1111/j.1745-6606.1996.tb00729.x

Mason, C., \& Perreault, W. D. Jr. (1991). Collinearity, power, and interpretation of multiple regression analysis. JMR, Journal of Marketing Research, 28(3), 268-280. doi:10.1177/002224379102800302

Massey, A. P., Khatri, V., \& Montoya-Weiss, M. M. (2007). Usability of online services: The role of technology readiness and context. Decision Sciences, 38(2), 277-308. doi:10.1111/j.1540-5915.2007.00159.x

Mattila, A. S., \& Wirtz, J. (2008). The role of store environmental stimulation and social factors on impulse purchasing. Journal of Services Marketing, 22(7), 562-567. doi:10.1108/08876040810909686

Mauri, A. G., \& Minazzi, R. (2013). Web reviews influence on expectations andpurchasing intentions of hotel potential customers. International Journal of Hospitality Management, 34, 99-107. doi:10.1016/j. ijhm.2013.02.012

McPherson, M., Smith-Lovin, L., \& Cook, J. M. (2001). Birds of a feather: Homophilyin social network. Annual Review of Sociology, 27(1), 415-444. doi:10.1146/annurev.soc.27.1.415

Mehrabian, A., \& Russell, J. A. (1974). An approach to environmental psychology. The MIT Press.

Mudambi, S. M., \& Schuff, D. (2010). What makes a helpful online review? a study of customer reviews on amazon.com. Management Information Systems Quarterly, 34(1), 185-200. doi:10.2307/20721420

Muniz, A. M. Jr, \& O'Guinn, T. C. (2001). Brand community. The Journal of Consumer Research, 27(4), 412-432. doi:10.1086/319618

Murray, S. L., Holmes, J. G., Bellavia, G., Griffin, D. W., \& Dolderman, D. (2002). Kindred spirits?The benefits of egocentrism in close relationships. Journal of Personality and Social Psychology, 82(4), 563-581. doi:10.1037/0022-3514.82.4.563 PMID:11999924

Newsted, P. R., Huff, S. L., \& Munro, M. C. (1998). Survey instruments in information systems. Management Information Systems Quarterly, 22(4), 553-554. doi:10.2307/249555

Olbrich, R., \& Holsing, C. (2011). Modeling consumer purchasing behavior in socialshopping communities with clickstream data. International Journal of Electronic Commerce, 16(2), 15-40. doi:10.2753/JEC1086-4415160202

Overby, J. W., \& Lee, E. J. (2006). The effects of utilitarian and hedonic online shopping value on consumer preference and intentions. Journal of Business Research, 59(10), 1160-1166. doi:10.1016/j.jbusres.2006.03.008

Palumbo, F., \& Herbig, P. (2000). The multicultural context of brand loyalty. European Journal of Innovation Management, 3(3), 116-124. doi:10.1108/14601060010334876

Paridon, T. J., Carraher, S., \&Carraher, S. C. (2006). The income effect in personal shopping value, consumer selfconfidence, and information sharing (word of mouth communication) research. The Dream Catchers Group LLC.

Park, C. W., \& Moon, B. J. (2003). The relationship between product involvement and product knowledge: Moderating roles of product type and product knowledge type. Psychology and Marketing, 20(11), 977-997. doi:10.1002/mar.10105

Phang, C. W., Zhang, C., \& Sutanto, J. (2013). The influence of user interaction andparticipation in social media on the consumption intention of niche products. Information \& Management, 50(8), 661-672. doi:10.1016/j. im.2013.07.001

Podsakoff, P. M., MacKenzie, S. B., Lee, J.-Y., \& Podsakoff, N. P. (2003). Common method biases in behavioral research: A critical review of the literature and recommended remedies. The Journal of Applied Psychology, 88(5), 879-903. doi:10.1037/0021-9010.88.5.879 PMID:14516251

Podsakoff, P. M., \& Organ, D. W. (1986). Self-reports in organizational research: Problems and prospects. Journal of Management, 12(4), 531-544. doi:10.1177/014920638601200408

Preacher, K. F., \& Hayes, A. F. (2008). Asymptotic and resampling strategies for assessing and comparing indirect effects in multiple mediator models. Behavior Research Methods, 40(3), 879-891. doi:10.3758/BRM.40.3.879 PMID:18697684 
Reagans, R. E., \& Burt, R. S. (1998). Homophily, legitimacy, and competition: bias inmanager peer evaluations. Annual Meetings of the American Sociological Association.

Rosenberg, M. (1979). Conceiving the Self. Basic Books.

Schembri, S., Merrilees, B., \& Kristiansen, S. (2010). Brand consumption and narrative of the self. Psychology and Marketing, 27(6), 623-637. doi:10.1002/mar.20348

Shan, Y. (2016). How credible are online product reviews? The effects ofself-generated and system-generated cues on source credibility evaluation. Computers in Human Behavior, 55, 633-641. doi:10.1016/j.chb.2015.10.013

Shen, X. L., Lee, M. K., \& Cheung, C. M. (2014). Exploring online social behavior in crowd-sourcing communities: A relationship management perspective. Computers in Human Behavior, 40, $144-151$. doi:10.1016/j.chb.2014.08.006

Shen, Y. C., Huang, C. Y., Chu, C. H., \& Liao, H. C. (2010). Virtual community loyalty:An interpersonalinteraction perspective. International Journal of Electronic Commerce, 15(1), 49-74. doi:10.2753/JEC10864415150102

Siering, M., Muntermann, J., \& Rajagopalan, B. (2018). Explaining and predicting online review helpfulness: The role of content and reviewer-related signals. Decision Support Systems, 108, 108. doi:10.1016/j.dss.2018.01.004

Sirgy, M. J. (1985). Using self-congruity and ideal congruity to predict purchase motivation. Journal of Business Research, 13(3), 195-206. doi:10.1016/0148-2963(85)90026-8

Sirgy, M. J., Grewal, D., Mangleburg, T. F., Park, J., Chon, K. S., Claiborne, C. B., Johar, J. S., \& Berkman, H. (1997). Assessing the predictive validity of two methods of measuring self-image congruence. Journal of the Academy of Marketing Science, 25(3), 229-241. doi:10.1177/0092070397253004

Smith, D., Menon, S., \& Sivakumar, K. (2005). Online peer and editorialrecommendations, trust, and choice in virtual markets. Journal of Interactive Marketing, 19(3), 15-37. doi:10.1002/dir.20041

Sprott, D., Czellar, S., \& Spangenberg, E. (2009). The Importance of a General Measure of Brand Engagement on Market Behavior: Development and Validation of a Scale. JMR, Journal of Marketing Research, 46(1), 92-104. doi:10.1509/jmkr.46.1.92

Symons, C. S., \& Johnson, B. T. (1997). The self-reference effect in memory: A meta-analysis. Psychological Bulletin, 121(3), 371-394. doi:10.1037/0033-2909.121.3.371 PMID:9136641

Tajfel, H., \& Turner, J. C. (1979). An integrative theory of intergroup conflict. In W. G. Austin \& S. Worchel (Eds.), The social psychology of intergroup relations (pp. 33-47). Brooks-Cole.

Tamilmani, K., Rana, N. P., Prakasam, N., \& Dwivedi, Y. K. (2019). The battle of brain vs. heart: A literature review and meta-analysis of "hedonic motivation" use in UTAUT2. International Journal of Information Management, 46, 222-235. doi:10.1016/j.ijinfomgt.2019.01.008

Tamjidyamcholo, A., Gholipour, R., Baba, M. S. B., \& Yamchello, H. T. (2013). Information security professional perceptions of knowledge-sharing intention in virtual communities under social cognitive theory. In Research and innovation in information systems (ICRIIS). In 2013 international conference on, IEEE 2013 (pp. 416-421). doi:10.1109/ICRIIS.2013.6716746

Tauber, E. M. (1972). Why do people shop? Journal of Marketing, 46-49.

Topaloglu, O., \& Dass, M. (2019). The impact of online review content and linguistic style matching on new product sales: The moderating role of review helpfulness. Decision Sciences, deci.12378. doi:10.1111/deci.12378

Verhoef, P. C., Reinartz, W., \& Krafft, M. (2010). Customer Engagement as a New Perspective in Customer Management. Journal of Service Research, 13(3), 247-252. doi:10.1177/1094670510375461

Woodside, A. G., \& Davenport, J. W. Jr. (1974). The effect of salesman similarity andexpertise on consumer purchasing behavior. JMR, Journal of Marketing Research, 11(2), 198-202. doi:10.1177/002224377401100212

Wu, W. Y., Quyen, P. T. P., \& Rivas, A. A. A. (2017). How e-servicescapes affect customer online shopping intention: The moderating effects of gender and online purchasing experience. Information Systems and e-Business Management, 15(3), 689-715. doi:10.1007/s10257-016-0323-x 
Xiang, L., Zheng, X., Lee, M. K., \& Zhao, D. (2016). Exploring consumers' impulse buying behavior on social commerce platform: The role of parasocial interaction. International Journal of Information Management, 36(3), 333-347. doi:10.1016/j.ijinfomgt.2015.11.002

Yang, W., \& Mattila, A. S. (2014). Do affluent customers care when luxury brands gomass? The role of product type and status seeking on luxury brand attitude. International Journal of Contemporary Hospitality Management, 26(4), 526-543. doi:10.1108/IJCHM-03-2013-0124

Yaniv, I., Choshen-Hillel, S., \& Milyavsky, M. (2011). Receiving advice on matters oftaste: Similarity, majority influence, and caste discrimination. Organizational Behavior and Human Decision Processes, 115(1), 111-120. doi:10.1016/j.obhdp.2010.11.006

Zhao, H., Sullivan, K. P. H., \& Mellenius, I. (2014). Participation, interaction and social presence: Anexploratory study of collaboration in online peer review groups. British Journal of Educational Technology, 45(5), 807-819. doi:10.1111/bjet.12094

Zhao, X., Lynch, J. G. Jr, \& Chen, Q. (2010). Reconsidering Baron and Kenny: Myths and truths about mediation analysis. The Journal of Consumer Research, 37(2), 197-206. doi:10.1086/651257 


\section{APPENDICES}

\section{Appendix A}

\section{Measurement items}

\begin{tabular}{|c|c|c|}
\hline Constructs & Items & References \\
\hline $\begin{array}{l}\text { External similarity } \\
\text { (ES) }\end{array}$ & $\begin{array}{l}\text { ES1 The online reviews of this website have features that allow me to find } \\
\text { consumers with whom I share the same name. } \\
\text { ES2 The online reviews of this website have features that allow me to } \\
\text { recognize consumers with website I share the same period of lifespan. } \\
\text { ES3 The online reviews of this website have features that allow me to } \\
\text { identify consumers with whom I share a similar place of residence. }\end{array}$ & $\begin{array}{l}\text { (Shen et al., 2010; Shan, } \\
\text { 2016) }\end{array}$ \\
\hline Internal similarity (IS) & $\begin{array}{l}\text { IS1 The online reviews of this website have features that allow me to find } \\
\text { consumers with whom I share similar values. } \\
\text { IS2 The online reviews of this website have features that allow me to find } \\
\text { consumers with whom I share similar shopping styles. } \\
\text { IS3 The online reviews of this website have features that allow me to } \\
\text { recognize consumers with whom I share similar interests or hobbies. } \\
\text { IS4 The online reviews of this website have features that allow me to identify } \\
\text { consumers with whom I share similar consumption preferences. }\end{array}$ & (Shen et al., 2010) \\
\hline $\begin{array}{l}\text { Perceived utilitarian } \\
\text { value (PUV) }\end{array}$ & $\begin{array}{l}\text { PUV1Searching/reading for online reviews was useful. } \\
\text { PUV2 I was satisfied with the items I purchased after I searched/read the } \\
\text { online reviews. } \\
\text { PUV3 I accomplished just what I wanted to on the trip of searching/reading } \\
\text { for online reviews. } \\
\text { PUV4 While searching/reading for online reviews, I found just the reviews I } \\
\text { was looking for. }\end{array}$ & $\begin{array}{l}\text { Paridon et al., 2006; Edward } \\
\text { Shih-Tse, 2010) }\end{array}$ \\
\hline $\begin{array}{l}\text { Perceived hedonic } \\
\text { value (PHV) }\end{array}$ & $\begin{array}{l}\text { PHV1 Searching/reading for online reviews was enjoyable. } \\
\text { PHV2 Searching/reading for online reviews felt like an escape. } \\
\text { PHV3 I had a good time because I was able to act on the spur of the moment. } \\
\text { PHV4 I enjoyed searching/reading for online reviews for its own sake, not } \\
\text { just for the items I purchased. }\end{array}$ & $\begin{array}{l}\text { (Paridon et al., 2006; Shih- } \\
\text { Tse, 2010) }\end{array}$ \\
\hline $\begin{array}{l}\text { Self-image congruence } \\
\text { (SIC) }\end{array}$ & $\begin{array}{l}\text { SIC1 I admire people who purchased this brand (or this product). } \\
\text { SIC2 The typical consumer using this website has an image similar to how I } \\
\text { would like other people to see me. } \\
\text { SIC3 The typical consumer at this website is very much the kind of person I } \\
\text { would like others to see me as. }\end{array}$ & $\begin{array}{l}\text { (Sirgy et al.,1997; Back, } \\
\text { 2005; Hanks et al., 2017) }\end{array}$ \\
\hline $\begin{array}{l}\text { Self-brand congruence } \\
\text { (SBC) }\end{array}$ & $\begin{array}{l}\text { SBC1 This brand reflects who I am. } \\
\text { SBC2 I can identify with this brand. } \\
\text { SBC3 I could use this brand to communicate who I am to other people. } \\
\text { SBC4 I think this brand could help me become the type of person I want to } \\
\text { be. } \\
\text { SBC5 I consider this brand to be "me" (it reflects who I consider myself to } \\
\text { be or the way that I want to present myself to others). }\end{array}$ & $\begin{array}{l}\text { (Escalas \& Bettman, 2003; } \\
\text { Hanks et al., 2017) }\end{array}$ \\
\hline $\begin{array}{l}\text { Customer brand } \\
\text { engagement }(\mathrm{CBE})\end{array}$ & $\begin{array}{l}\text { CBE1 I spend a lot of time engaging this brand, compared to other social } \\
\text { commerce websites. } \\
\text { CBE2 Whenever I'm using professional social commerce sites, I usually use } \\
\text { this platform. } \\
\text { CBE3 This platform is one of the brands I usually use. }\end{array}$ & $\begin{array}{l}\text { (Hollebeek, Glynn, \& } \\
\text { Brodie, 2014) }\end{array}$ \\
\hline
\end{tabular}




\section{Appendix B}

\section{Common method bias analysis.}

\begin{tabular}{|c|c|c|c|c|c|}
\hline Construct & Indicator & $\begin{array}{l}\text { Substantive factor loading } \\
\text { (R1) }\end{array}$ & $\mathbf{R 1}^{2}$ & $\begin{array}{l}\text { Method factor loading } \\
\text { (R2) }\end{array}$ & $\mathbf{R}^{2}$ \\
\hline \multirow{3}{*}{$\begin{array}{l}\text { External } \\
\text { similarity }\end{array}$} & ES1 & $0.836 * * *$ & 0.699 & -0.034 & 0.011 \\
\hline & ES2 & $0.753 * * *$ & 0.567 & 0.081 & 0.007 \\
\hline & ES3 & $0.786 * * *$ & 0.618 & $0.165^{*}$ & 0.027 \\
\hline \multirow{4}{*}{$\begin{array}{l}\text { Internal } \\
\text { similarity }\end{array}$} & IS 1 & $0.826 * * *$ & 0.682 & -0.028 & 0.011 \\
\hline & IS2 & $0.827 * * *$ & 0.684 & -0.057 & 0.003 \\
\hline & IS3 & $0.823 * * *$ & 0.677 & 0.035 & 0.001 \\
\hline & IS4 & $0.861 * * *$ & 0.741 & 0.002 & 0.009 \\
\hline \multirow{4}{*}{$\begin{array}{l}\text { Perceived } \\
\text { utilitarian } \\
\text { value }\end{array}$} & PUV1 & $0.737 * * *$ & 0.543 & -0.037 & 0.001 \\
\hline & PUV2 & $0.845^{* * *}$ & 0.714 & 0.036 & 0.001 \\
\hline & PUV3 & $0.827 * * *$ & 0.684 & 0.054 & 0.003 \\
\hline & PUV4 & $0.826 * * *$ & 0.682 & 0.013 & 0.008 \\
\hline \multirow{4}{*}{$\begin{array}{l}\text { Perceived } \\
\text { hedonic value }\end{array}$} & PHV1 & $0.787 * * *$ & 0.619 & 0.124 & 0.015 \\
\hline & PHV2 & $0.798 * * *$ & 0.637 & -0.013 & 0.007 \\
\hline & PHV3 & $0.861 * * *$ & 0.741 & 0.021 & 0.002 \\
\hline & PHV4 & $0.895 * * *$ & 0.801 & 0.031 & 0.001 \\
\hline \multirow{3}{*}{$\begin{array}{l}\text { Self-image } \\
\text { congruence }\end{array}$} & SIC1 & $0.823 * * *$ & 0.677 & -0.013 & 0.000 \\
\hline & SIC2 & $0.896 * * *$ & 0.823 & 0.024 & 0.001 \\
\hline & SIC3 & $0.857 * * *$ & 0.734 & 0.003 & 0.010 \\
\hline \multirow{5}{*}{$\begin{array}{l}\text { Self-brand } \\
\text { congruence }\end{array}$} & $\mathrm{SBC} 1$ & $0.856^{* * *}$ & 0.733 & 0.000 & 0.000 \\
\hline & $\mathrm{SBC} 2$ & $0.863 * * *$ & 0.745 & 0.038 & 0.001 \\
\hline & SBC3 & $0.893 * * *$ & 0.797 & -0.018 & 0.015 \\
\hline & SBC4 & $0.902 * * *$ & 0.814 & -0.009 & 0.011 \\
\hline & SBC5 & $0.873 * * *$ & 0.762 & 0.032 & 0.001 \\
\hline \multirow{3}{*}{$\begin{array}{l}\text { Customer } \\
\text { brand } \\
\text { engagement }\end{array}$} & CBE1 & $0.798 * * *$ & 0.637 & 0.009 & 0.012 \\
\hline & CBE2 & $0.891^{* * *}$ & 0.794 & 0.033 & 0.001 \\
\hline & CBE3 & $0.886^{* * * *}$ & 0.785 & 0.017 & 0.000 \\
\hline Average & & 0.839 & 0.707 & 0.034 & 0.006 \\
\hline
\end{tabular}

${ }^{*} p<0.01 ;{ }^{* *} p<0.05 ;{ }^{* * *} p<0.001$. 


\section{Appendix C}

Item loading and cross-loadings.

\begin{tabular}{|c|c|c|c|c|c|c|c|}
\hline & ES & IS & PHV & PUV & SBC & SI & SIC \\
\hline ES1 & 0.789 & 0.404 & 0.322 & 0.415 & 0.178 & 0.346 & 0.235 \\
\hline ES2 & 0.816 & 0.452 & 0.381 & 0.425 & 0.146 & 0.184 & 0.142 \\
\hline ES3 & 0.735 & 0.347 & 0.349 & 0.308 & 0.201 & 0.205 & 0.239 \\
\hline IS1 & 0.530 & 0.769 & 0.292 & 0.366 & 0.187 & 0.228 & 0.206 \\
\hline IS2 & 0.465 & 0.884 & 0.316 & 0.412 & 0.219 & 0.181 & 0.237 \\
\hline IS3 & 0.401 & 0.868 & 0.389 & 0.400 & 0.303 & 0.210 & 0.294 \\
\hline IS4 & 0.309 & 0.768 & 0.280 & 0.266 & 0.232 & 0.129 & 0.329 \\
\hline PHV1 & 0.445 & 0.327 & 0.813 & 0.614 & 0.200 & 0.284 & 0.195 \\
\hline PHV2 & 0.312 & 0.277 & 0.787 & 0.394 & 0.267 & 0.163 & 0.289 \\
\hline PHV3 & 0.347 & 0.305 & 0.822 & 0.474 & 0.273 & 0.266 & 0.346 \\
\hline PHV4 & 0.284 & 0.322 & 0.723 & 0.307 & 0.377 & 0.077 & 0.441 \\
\hline PUV1 & 0.386 & 0.330 & 0.387 & 0.721 & 0.054 & 0.308 & 0.040 \\
\hline PUV2 & 0.380 & 0.329 & 0.444 & 0.789 & 0.257 & 0.311 & 0.240 \\
\hline PUV3 & 0.383 & 0.362 & 0.481 & 0.872 & 0.207 & 0.374 & 0.155 \\
\hline PUV4 & 0.432 & 0.392 & 0.552 & 0.820 & 0.282 & 0.297 & 0.233 \\
\hline SBC1 & 0.176 & 0.210 & 0.277 & 0.196 & 0.856 & 0.331 & 0.621 \\
\hline $\mathrm{SBC} 2$ & 0.266 & 0.284 & 0.313 & 0.318 & 0.738 & 0.397 & 0.458 \\
\hline SBC3 & 0.197 & 0.207 & 0.256 & 0.144 & 0.842 & 0.225 & 0.665 \\
\hline SBC4 & 0.102 & 0.181 & 0.202 & 0.116 & 0.818 & 0.202 & 0.588 \\
\hline SBC5 & 0.164 & 0.292 & 0.345 & 0.269 & 0.856 & 0.268 & 0.609 \\
\hline SI1 & 0.303 & 0.211 & 0.262 & 0.395 & 0.310 & 0.919 & 0.295 \\
\hline SI2 & 0.279 & 0.191 & 0.210 & 0.369 & 0.332 & 0.950 & 0.292 \\
\hline SI3 & 0.297 & 0.233 & 0.261 & 0.358 & 0.340 & 0.924 & 0.249 \\
\hline CBE1 & 0.231 & 0.249 & 0.374 & 0.184 & 0.615 & 0.262 & 0.871 \\
\hline CBE2 & 0.241 & 0.325 & 0.334 & 0.169 & 0.691 & 0.272 & 0.916 \\
\hline CBE3 & 0.230 & 0.293 & 0.347 & 0.216 & 0.744 & 0.273 & 0.908 \\
\hline
\end{tabular}


Senhui FU(PhD, Sun Yat-sen University, 2018) is an assistant professor in the School of Management, Guangdong University of Technology. Her researches focus on consumer behavioris, brand management and social media marketing.

Qing Yan (PhD, Sichuan University, 2013) is a professor in the School of Journalism and Communication at Jinan University. His research focuses on entertainment and media culture especially in the context of new media. He is interested in examining fan cultures using the grounded theory approach and mixed methods. Corresponding author: Qing Yan (yanqing2008@163.com)

Guangchao Charles Feng (Ph.D., Hong Kong Baptist University) is a distinguished professor of communication at Shenzhen University, China. Dr. Feng has published around 30 research articles in prestigious SSCl-listed international journals, such as Communication Research, Journalism and Mass Communication Quarterly, International Journal of Communication, Asian Journal of Communication, Chinese Journal of Communication, Telematics and Informatics, Methodology, International Communication Gazette, International Journal of Information Management, and Asia Pacific Business Review, among others. In addition, Dr. Feng serves on the editorial boards of several SSCI-listed journals, such as Mass Communication and Society and the Chinese Journal of Communication. He is the senior editor of Cogent Social Sciences (an E-SCI listed journal owned by Taylor \& Francis). His research interests are big-data-based new media studies, advertising, health communication, and political communication. 